\title{
Employment and Learning in the Context of the Quality of Working Life
}

\author{
Zuzana Dvorakova \\ MIAS School of Business \\ Czech Technical University in Prague \\ Prague 6, Czech Republic \\ Zuzana.Dvorakova@cvut.cz
}

\author{
Ilona A. Polents \\ Dep. of Business Economics \\ University of West Bohemia \\ Pilsen, Czech Republic \\ watt@bk.ru
}

\author{
Iveta Nemeckova \\ MIAS School of Business \\ Czech Technical University in Prague \\ Prague 6, Czech Republic \\ Iveta.Nemeckova@cvut.cz
}

\begin{abstract}
The society and labor markets are preparing for the global competition with robots, artificial intelligence, and the Internet of things. By addressing the bibliometric research deficit from an international literature perspective, this study explores the thematic evolution and the state of employability, lifelong learning, and the quality of working life concerning the internationally accredited scientific databases: Web of Science and Scopus. The presented paper gives an overview of previous studies, conducting the two last decades on the issues of the mentioned above terms. The analysis is limited by the most significant works, considering the citation index, related to employability, lifelong learning, and making managerial decisions that directly affect the quality of working life. The results indicate an increase in discussions around the effectiveness of proactive activating learning methods, and their impact on the employability and the quality of life issues. Finally, the paper contributes to the literature in the field under study and makes recommendations for future longitudinal studies.
\end{abstract}

Keywords: employment, employability, lifelong learning, quality of working life

\section{INTRODUCTION}

The society is evolving dynamically, and the quality of life becomes the concern of the state, employers, and the individual. As welfare increases, the importance of a perception of the quality of life will increase. Methods of its objective improvement mainly concentrate in the field of medicine. Indicators of its subjective perception include a wide range of aspects of life and work. Quality of life surveys give an insight into what factors are essential to humans, how they are fulfilled, and change over time. Preferences receive human values, health, interpersonal relationships, work, and working conditions. Education and lifelong learning have a special place in the quality of life by creating conditions for employability and the quality of working life (QWL). Work 4.0 will require entrepreneurial competencies and lifelong learning for employers to sustain competitively and generate innovations.

The aim of the paper is the following:

- To characterize efforts in the field of employability, lifelong learning and QWL using bibliometrics analysis of bibliographic data on the topic,

- To identify perspectives in the area of lifelong learning,
- To illustrate experience and opinions of top managers about university students in the Czech Republic in two case studies.

\section{Literature REVIEW AND RESEARCH METHOdS}

\section{A. Literature review}

Employability and lifelong learning are becoming increasingly of interest to politicians and employers as a result of the EU enlargement context and the economic crisis of 2008-2012. Studies address Europe's diversity in education, the ability to identify competency profiles as required by employers across borders and achieve a balance between flexibility and employment security at the national level [1], [2].

Over the past decades, there has been an evident shift; it is no longer about employment but about employability. Fejes [3] argues that the individual is personally responsible for his/her employability and that the state and employer are in the role of helping. Lifelong learning of the worker has positive effects on all aspects of sustainable employment, i.e., employability, workability, and vitality. Van Vuuren, Caniels, and Semeijn [4] believe that the interaction between age and lifelong learning has significant effects on employability and workability. They argue that older workers maintain their employability and workability when they are interested in and perceive more opportunities for lifelong learning. Examples of good practices for maintaining employability include training, lifelong learning and knowledge transfer, flexible working, health protection, and promotion design, career development, and mobility management [5]. A critical milestone for keeping social reconciliation is increasing social polarization and economic uncertainty when lifelong learning can function as significant protection by keeping adults close to a changing labor market [6].

Discussions on the concept of education for sustainable employability and lifelong learning concentrate on labor market needs and job competency models [7], [8]. Training programs providing occupation-specific skills with immediate labor market relevance repeatedly show to secure safe pathways into employment, but cannot guarantee lifelong employability [9] Employability skills required by Work 4.0 include hard and soft skills, like communication skills, problem-solving and decision-making skills, and teamwork skills, and personal characteristics, e.g., selfawareness, self-confidence, independence, emotional intelligence, flexibility and adaptability, stress tolerance, 
England (584), Spain (494), Romania (337), Germany (271), and People Republic of China (269). In the CR, it includes 122 publications.

Studies about QWL according to categories focus on management (58 publications), public environmental and occupational health (47), economics (30), nursing (29), industrial relations labor (28), and applied psychology (23).

The literature between 2012 and 2019 was used since this period increased the number of publications about the works related to employability and lifelong learning, as shown in Table II.

TABLE I. BIBLIOGRAPHIC RECORDS IN WEB OF SCIENCE AND SCOPUS DATABASE 1999-2019

\begin{tabular}{|l|l|l|}
\hline \multirow{2}{*}{\multicolumn{1}{|c|}{ Query }} & \multicolumn{2}{c|}{ Bibliographic Records a } \\
\cline { 2 - 3 } & \multicolumn{1}{|c|}{ Web of Science } & \multicolumn{1}{c|}{ Scopus } \\
\hline Employment & 122708 & 195558 \\
\hline Employability & 5105 & 6672 \\
\hline Lifelong learning & 6054 & 9088 \\
\hline Life-long learning & 43 & 3390 \\
\hline Quality of working life & 331 & 929 \\
\hline Total & 134241 & 215637 \\
\hline \multicolumn{2}{|c|}{${ }^{\text {a. Calculated by the authors }}$} \\
\hline
\end{tabular}

TABLE II. BIBLIOGRAPHIC RECORDS BY QUERIES IN WEB OF SCIENCE 1999-2019 interviews about university students and education in the Czech environment, we summarize their findings in two case studies.

The reason for using these methods is that the topic deals with social phenomena that are determined by the national culture, values, and behavior of people and whose changes influence a situational socio-economic system. The paper includes on-the-desk analyzes of secondary sources that reveal trends. Unstructured interviews with two top managers of multinational consultancy companies identify opinions about their approaches to developing HR strategies, people staffing, and training. A combination of these research methods provides a rational ground for predictions which areas of future research can expect.

\section{RESULTS}

\section{A. Analysis of bibliographic data}

We retrieved 349878 bibliographic records that matched the query in database search: records from the Web of Science databases count for 134241 and Scopus 215637 . Their structure of bibliographic records shows Table I. The enormous amount of literature of various sciences does not allow conducting a complete analysis of all of them. In this paper, the analysis is limited by the most significant works, considering the citation index related to employability, lifelong learning, and QWL. The study outlines the development of promising directions in several areas of the economy, the labor economy, and human resource management.

Employability belongs to the most studied topics in England (887 publications in the Web of Science), US (491), Spain (469), Australia (434), People Republic of China (291), and Netherlands (280). In the CR, it covers 60 publications.

In the case of lifelong learning, the order of the number of publications characterizes the following: US (998),

\begin{tabular}{|l|l|l|l|l|l|l|l|}
\hline \multicolumn{1}{|c|}{ Query } & \multicolumn{7}{|c|}{ Years } \\
\cline { 2 - 9 } & $\mathbf{1 9 9 9}$ & $\mathbf{2 0 1 2}$ & $\mathbf{2 0 1 4}$ & $\mathbf{2 0 1 6}$ & $\mathbf{2 0 1 7}$ & $\mathbf{2 0 1 8}$ & $\mathbf{2 0 1 9}$ \\
\hline Employability & 29 & 237 & 416 & 599 & 760 & 714 & 620 \\
\hline $\begin{array}{l}\text { Lifelong } \\
\text { learning }\end{array}$ & 72 & 417 & 447 & 579 & 590 & 549 & 401 \\
\hline $\begin{array}{l}\text { Quality of } \\
\text { working life }\end{array}$ & 8 & 13 & 14 & 31 & 41 & 40 & 21 \\
\hline \multicolumn{9}{|c|}{} \\
\hline
\end{tabular}

\section{B. Case studies}

Two unstructured interviews with top managers - coowners of multinational consultancy companies located in the CR provide data for two case studies. They are an illustration of what job requirements they expect for staffing a business analyst position and how they evaluate the behavior and attitudes of university students to learning. The interviews use findings from marketing studies summarized under the heading of employer branding [24].

Case study 1. Radek is a co-owner of a multinational consulting firm that operates worldwide and whose organizational structure acts as a network of independent local entities. The Czech branch is fully autonomous, and its core business covers consulting for the energy sector. The critical human resource processes are managed by the branch manager, which involves making decisions about selection, doing performance management, coaching, deciding about promotion, and remuneration. Recruitment targets students and recent graduates, regardless of university and field of study. They are usually addressed directly, and the preference becomes word-of-mouth by current or former employees. Digital competence and language skills are a prerequisite for passing a pre-selection phase. The selection procedure includes a case study from a real business (usually a case solved by the company for its clients) and an interview with the co-owner. The decisive criterium for accepting the job candidate is his/her broad knowledge (ideally in the 
technical, life, and social sciences), willingness to learn, and ability to find unconventional solutions, share experiences and collaborate in a team.

Case study 2. Pavel is a co-owner of a multinational consultancy company whose branches are in most European countries. The company specializes in corporate training and development, coaching, a consultancy in design competency models. The Czech branch belongs to the category of microenterprise, which cooperates with an extensive network of independent consultants. Since 1992, the managing partner has been giving lectures to full-time students at universities and can compare how their behavior and attitudes towards education have changed over the past 25 years. He perceives that students' attention and interest in lectures given by businessmen decrease. He thinks that students mainly focus on their employment and studying at a university see as an additional burden, as jobs they need for earning money and study losing for them additional value. They take learning, e.g., doing homework and reading recommended literature, less seriously. Students are mostly passive, unwilling to be involved in interactive teaching, and in discussions because as they do not want to go out of the crowd and lose face in front of others. When they solve case studies, a team solution prevails without a multidisciplinary interconnection with other areas. Discussions tend to be full of general phrases from outdated textbooks, without understanding relations between theory and practice, low level of knowledge about both historical and current business topics. During lessons, students rely on pre-prepared presentations that they are used to read and are not familiar with the contents.

\section{DISCUSSION}

Automation and robotics increase the demand for technical knowledge and skills to solve problems and generate innovation, especially in professions related to science, technology, engineering, and mathematics. In addition to primary education, continuing vocational training should ensure that workers can operate new technologies. Open sources for lifelong learning create the potential for easy mobility between jobs, professions, and economic activities. In both parts of education, both cognitive and noncognitive competencies are concerned, with non-cognitive acquired in early childhood, and at school, one must be persistent and purposeful, is interested in learning, and the ICT infrastructure supports providing mass online courses.

High-quality qualifications obtained at schools and universities significantly increase employability. It is vital for employers that vocational higher education and other training be relevant to practice, for example, by extending qualification profiles, integrating key work competencies into study programs, and utilizing proactive and interactive learning methods in a massive way.

In many localities, the reality of education is far from government strategies and policies. F. T. Sáez gives brilliant comments on the situation in the education system in the context of digital transformation at the SELFIE Forum organized by the European Commission in April 2019 [25]. He said that although many teachers would like to participate in transforming education, they face constraints because they work in an institution that is slow, rigid, and refuses to change. He summed up the importance of ending the debate that teachers themselves are crucial to innovation and transformation in education. The crucial step for the future is to connect schools with practice and to involve companies in the education system.

\section{CONCLUSION}

The bibliometric analysis revealed the main trends in employability, lifelong learning, and QWL studies and identified promising areas for further work. The importance of lifelong learning has grown steadily over the past 20 years. Demands for hard and soft skills of the workforce are increasing, and great emphasis puts on entrepreneurial competencies. Innovations in education influence factors such as: (1) a labor market situation, (2) funds declared and distributed to educational institutions, (3) the position and role of educators in society and the economy, (4) cooperation between educational institutions and business, and (5) the values of young people and their attitudes towards learning.

Employability supports lifelong learning, in which proactive and interactive methods are the most effective. In the CR, educational reforms have a short lifetime. The stabilization of education depends on the political culture and continuity of school reforms. Employers treat employees' lifelong learning pragmatically and declare their interest in creating opportunities for practical training.

\section{ACKNOWLEDGMENT}

The paper is supported by the OP Prague - Pole of Growth of the Czech Republic. CZ.07.1.02/0.0/0.0/17_049/0000835. Neurotechnology to Improve the Quality of Life and Cyberbullying Prevention in Society 4.0. CTU in Prague. Period: 1.2.2019 - 31. 7.2021.

\section{REFERENCES}

[1] M. Brockmann, L. Clarke and Ch. Winch, "Knowledge, skills, competence: European divergences in vocational education and training (VET) - the English, German and Dutch cases," Oxford Review of Education, vol. 34, iss. 5, pp. 547-567, 2008.

[2] A. Kornelakis, "Balancing flexibility with security in organizations? Exploring the links between flexicurity and human resource development," Human Resource Development Review, vol. 13, iss. 4 , pp. 398-412, 2014.

[3] A. Fejes, "Discourses on employability: constituting the responsible citizen," Studies in Continuing Education, vol. 32, iss. 2, pp. 89-102, 2010 .

[4] T. van Vuuren, M. C. J. Caniels and J. H. Semeijn, "Sustainable employability and lifelong learning," Gedrag \& Organisatie, vol. 24, iss. 4, pp. 357-374, 2011.

[5] F. Frerichs, R. Lindley, P. Aleksandrowicz et al., "Active ageing in organisations: a case study approach," International Journal of Manpower, vol. 33, iss. 6, pp. 666-684, 2012.

[6] K. Evans, I. Schoon and M. Weale, "Can lifelong learning reshape life chances?" British Journal of Educational Studies, vol. 61, iss. 1, SI, pp. 25-47, 2013.

[7] S. Pavlin, "Considering university-business cooperation modes from the perspective of enterprises," European Journal of Education, vol. 51, iss. 1, SI, pp. 25-39, 2016.

[8] E. Quendler and M. Lamb, "Learning as a lifelong process - meeting the challenges of the changing employability landscape: competences, skills and knowledge for sustainable development," International Journal of Continuing Engineering Education and Life-long Learning, vol. 26, iss. 3, pp. 273-293, 2016.

[9] J. Lavrijsen and I. Nicaise, "Returns on vocational education over the life cycle: Between immediate labour market preparation and lifelong employability," International Review of Education, vol. 63, iss. 2, pp. 257-280, 2017.

[10] M. Suarta, I. K. Suwintana, I. G. P. Sudhana Fajar Pranadi et. al. "Employability skills required by the 21 st century workplace: A literature review of labour market demand," Proceeding of the 
psychological well-being," Family Business Review, vol. 30, iss. 3, international conference on technology and vocational teachers (ICTVT 2017), Yogyakarta, Indonesia, vol. 102, pp. 337-342, 2017.

[11] Ch. R. Stoner and J. B. Stoner, "How can we make this work? Understanding and responding to working parents of children with autism," Business Horizons, vol. 57, iss. 1, pp. 85-95, 2014.

[12] D. Courpasson and V. Monties, "I am my body". Physical selves of police officers in a changing institution", Journal of Management Studies, vol. 54, iss. 1, pp. 32-57, 2017.

[13] K. B. Follmer and K. S. Jones, "Mental illnes in the workplace: An interdisciplinary review and organizational research agenda," Journal of Management, vol. 44, iss. 1, pp. 325-351, 2018.

[14] G. Menzio, I. A. Telyukova and L. Visschers, "Directed search over the life cycle," Review of Economic Dynamics, vol. 19, SI, pp. 38-62, 2016.

[15] M. S. Andrade and J. H. Westover, "Generational differences in work quality characteristics and job satisfaction," Evidence-based HRM A global forum empirical scholarship, vol. 6, iss. 3, pp. 287-304, 2018.

[16] K. M. Shockley and T. D. Allen, "When flexibility helps: Another look at the availability of flexible work arrangements and workfamily conflict," Journal of Vocational Behavior, vol. 71, iss. 3, pp. 479-493, 2007.

[17] R. Gawlik and G. Jacobsen, "Work-life balance decision-making of Norwegian students: Implications for human resources management," Entrepreneurial Business and Economics Review, vol. 4, iss. 4, pp. 153-170, 2016.

[18] M. Houshmand, M-D. L. Seidel and D. G. Ma, "The impact of adolescent work in family business on Child-Parent relationships and

[19] P. Howley, "Less money or better health? Evaluating individual's willingness to make trade-offs using life satisfaction data," Journal of Economic Behavior and Organization, vol. 135, pp. 53-65, 2017.

[20] Ollo-Lopez and S. Goni-Legaz, "Differences in work-family conflict: Which individual and national factors explain them?" International Journal of Human Resource Management, vol. 28, iss. 3, pp. 499-525, 2017.

[21] D. Wheatley and C. Bickerton, "Subjective well-being and engagement in arts, culture and sport," Journal of Cultural Economics, vol. 41, iss. 1, pp. 23-45, 2017.

[22] K. Gundolf, A. Jaouen and J. Gast, "Motives for strategic alliances in cultural and creative industries," Creativity and Innovation Management, vol. 27, iss. 2, pp. 148-160, 2018.

[23] Pritchard, "Statistical Bibliography or Bibliometrics?", Journal of Documentation, vol. 25, iss. 4, pp. 348-349, 1969.

[24] P. Jilkova, "Brands we love or know on the Czech financial market," in Marketing identity: Brands we love - part II, L. Petranova and Z. Bezakova, Eds. Trnava: University of SS. Cyril and Methodus, 2016, pp. $118-126$

[25] F. T. Sáez. European Commission, SELFIE Forum - teaching and learning in the digital age, 4-5 April 2019, Madrid, Luxemburg: Publications Office of the European Union, 2019, doi:10.2760/799301, JRC117482. 